\title{
Identification and analysis of low-molecular-weight dissolved organic carbon in subglacial basal ice ecosystems by ion chromatography
}

\author{
Emily C. O’Donnell ${ }^{1,2}$, Jemma L. Wadham ${ }^{2}$, Grzegorz P. Lis ${ }^{2}$, Martyn Tranter ${ }^{2}$, Amy E. Pickard $^{3}$, Marek Stibal $^{4}$, \\ Paul Dewsbury ${ }^{5}$, and Sean Fitzsimons ${ }^{6}$ \\ ${ }^{1}$ School of Geography, University of Nottingham, University Park, Nottingham, NG7 2RD, UK \\ ${ }^{2}$ Bristol Glaciology Centre, School of Geographical Sciences, University Road, Bristol, BS8 1SS, UK \\ ${ }^{3}$ School of Geosciences, University of Edinburgh, Kings Buildings, West Mains Rd, Edinburgh, EH9 3JN, UK \\ ${ }^{4}$ Department of Ecology, Charles University in Prague, Vinicna 7, 12844 Prague 2, Czech Republic \\ ${ }^{5}$ Thermo Fisher Scientific, Stafford House, 1 Boundary Park, Hemel Hempstead, Hertfordshire HP27 GE4, UK \\ ${ }^{6}$ Department of Geography, University of Otago, P.O. Box 56, Dunedin, Otago 9056, New Zealand
}

Correspondence to: Emily C. O’Donnell (emily.o’donnell@ nottingham.ac.uk)

Received: 23 July 2015 - Published in Biogeosciences Discuss.: 27 August 2015

Revised: 11 April 2016 - Accepted: 13 June 2016 - Published: 1 July 2016

\begin{abstract}
Determining the concentration and composition of dissolved organic carbon (DOC) in glacial ecosystems is important for assessments of in situ microbial activity and contributions to wider biogeochemical cycles. Nonetheless, there is limited knowledge of the abundance and character of DOC in basal ice and the subglacial environment and a lack of quantitative data on low-molecular-weight (LMW) DOC components, which are believed to be highly bioavailable to microorganisms. We investigated the abundance and composition of DOC in basal ice via a molecular-level DOC analysis. Spectrofluorometry and a novel ion chromatographic method, which has been little utilized in glacial science for LMW-DOC determinations, were employed to identify and quantify the major LMW fractions (free amino acids, carbohydrates, and carboxylic acids) in basal ice from four glaciers, each with a different type of overridden material (i.e. the pre-entrainment sedimentary type such as lacustrine material or palaeosols). Basal ice from Joyce Glacier (Antarctica) was unique in that $98 \%$ of the LMW-DOC was derived from the extremely diverse free amino acid (FAA) pool, comprising 14 FAAs. LMW-DOC concentrations in basal ice were dependent on the bioavailability of the overridden organic carbon (OC), which in turn was influenced by the type of overridden material. Mean LMW-DOC concentrations in basal ice from Russell Glacier (Greenland), Finster-
\end{abstract}

walderbreen (Svalbard), and Engabreen (Norway) were low $(0-417 \mathrm{nMC})$, attributed to the relatively refractory nature of the $\mathrm{OC}$ in the overridden palaeosols and bedrock. In contrast, mean LMW-DOC concentrations were an order of magnitude higher (4430 nMC) in basal ice from Joyce Glacier, a reflection of the high bioavailability of the overridden lacustrine material ( $>17 \%$ of the sediment OC comprised extractable carbohydrates, a proxy for bioavailable OC). We find that the overridden material may act as a direct (via abiotic leaching) and indirect (via microbial cycling) source of DOC to the subglacial environment and provides a range of LMW-DOC compounds that may stimulate microbial activity in wet subglacial sediments.

\section{Introduction}

Basal ice forms part of the subglacial environment, which also includes subglacial sediments and subglacial waters (Hodson et al., 2008). It hosts viable microbial communities that may play a significant role in the organic carbon (OC) turnover in glaciated regions (Sharp et al., 1999; Skidmore et al., 2000; Foght et al., 2004). Basal ice is typically defined as ice that has acquired distinctive physical and/or chemical characteristics due to processes operating at or near to the bed 
of an ice mass (Hubbard et al., 2009). Basal ice layers may comprise ice and debris entrained from beneath the glacier and meteoric ice derived from the surface and diagenetically modified by hydraulic, thermal, and strain conditions at the glacier bed (Knight, 1997). A range of processes can form basal ice, which we highlight briefly. For instance, new basal ice may form from basal accretion of supercooled subglacial water, a freeze-on (or adfreezing) mechanism (Lawson et al., 1998), or by regelation, the localized melting and refreezing of ice at the glacier bed, e.g. around a bedrock obstacle, which represents an important mechanism to entrain subglacial debris into the basal ice (Iverson and Semmens, 1995). Sediment may also be incorporated into basal ice by folding (Hubbard and Sharp, 1989), cavity/crevasse infilling, structural deformation, thrusting, traction/shearing, and metamorphism of existing ice at the glacier bed (Knight, 1997). Metamorphosis of meteoric glacier ice can thicken basal ice layers (Sharp et al., 1994), and post-formational tectonic deformation of basal ice can cause intermixing of glacier and basal ice (Waller et al., 2000).

The chemical composition of basal ice reflects characteristics of the parent water prior to being frozen (Knight, 1997). In temperate and polythermal glaciers, this may include supraglacial inputs, whereas in cold-based glaciers where there is little surface meltwater penetration, the majority of meltwater at the glacier bed likely derives from basal ice melting. This water may flow at the base of the glacier, be held in porewaters in overridden water-saturated sediment, or represent refrozen water from pressure melting during the regelation process. The parent water has potential to acquire dissolved compounds (including dissolved organic carbon (DOC) and low molecular weight (LMW)-DOC) via biogeochemical interactions with the overridden subglacial material. To date, there has been only limited examination of the potential for different bedrock types and overridden organic matter, such as palaeosols and lacustrine material (Wadham et al., 2008; Stibal et al., 2012), to act as a source of bioavailable DOC to basal ice, subglacial meltwater, and runoff, either directly (via abiotic leaching or in situ abiotic processes such as dissolution in water films around basal debris and in liquid water veins; Mader et al., 2006) or indirectly (via microbial cycling). Further knowledge is needed to determine the abundance and composition of potentially bioavailable LMW-DOC in basal ice at the base of glaciers and ice sheets and the implications this may have on subglacial DOC cycling.

OC cycling in the subglacial environment can be investigated by incubation experiments that monitor DOC decline and/or biogenic gas $\left(\mathrm{CO}_{2}\right.$ and $\left.\mathrm{CH}_{4}\right)$ production (Montross et al., 2012; Stibal et al., 2012) and provide a direct measure of bioavailability. Analysis of marker compounds in the DOC, such as free amino acids (FAAs) (Pautler et al., 2011), may provide an indirect assessment of bioavailability. These analyses may be complemented by fluorescence spectroscopy, where fluorescing components (fluorophores) are identified and associated with particular DOC compounds, e.g. protein-like and humic-like components. The proteinlike compounds are more easily utilized by aquatic heterotrophs when compared with the more aromatic humiclike components (Fellman et al., 2008) and are indicative of recent microbial activity (Barker et al., 2006, 2010). More recently, glacial DOC has been characterized at the molecular level by electrospray ionization (ESI) Fourier transform ion cyclotron resonance (FT-ICR) mass spectrometry (MS) (Grannas et al., 2006; Bhatia et al., 2010; Lawson et al., 2014a), and by solution-state ${ }^{1} \mathrm{H}$ nuclear magnetic resonance (NMR) spectroscopy (Pautler et al., 2011, 2012). Both methods have provided unprecedented high-resolution mass spectral information on DOC, but are not fully quantitative. Ion chromatography has been used to quantify a much smaller range of common LMW-DOC compounds, including carboxylic acids in ice cores and snow from Greenland, Antarctica, and alpine glaciers (Saigne et al., 1987; Maupetit and Delmas 1994; Tison et al., 1998). These LMWDOC compounds typically represent small fractions of the bulk DOC (Borch and Kirchmann, 1997), yet are believed to be highly bioavailable to microorganisms owing to their rapid turnover and uptake rates (Rich et al., 1997; Skoog and Benner, 1997). Ion chromatography has yet to be widely employed to determine the molecular structure of glacial LMW-DOC due to the trace analyte concentrations (Lawson et al., 2014b). Recent advances in ion chromatography instrumentation and system optimization (e.g. greater column sensitivities, low flow rates, multiple eluents, and gradient elution) enabled this study to identify and quantify numerous LMW-DOC compounds at low $(<70 \mathrm{nMC})$ concentrations, which demonstrates a novel methodological approach to glacial LMW-DOC analysis.

Here, we investigate the abundance and composition of LMW-DOC compounds (free amino acids, carbohydrates, and carboxylic acids) in debris-rich basal ice. We investigate four different glaciers with distinct temperature regimes, overridden substrates and, hence, contrasting sources of terrestrial organic matter. These glaciers were Joyce Glacier (Antarctica - lacustrine organic matter, cold-based), Russell Glacier (Greenland Ice Sheet, GrIS - palaeosols, polythermal), Finsterwalderbreen (Svalbard - bedrock with high OC, polythermal), and Engabreen (Norway - bedrock with low OC, temperate). We investigate whether LMW-DOC abundance in basal ice is influenced by the magnitude and bioreactivity of the $\mathrm{OC}$ in the overridden material.

\section{Sampling sites, basal ice description, and sample collection}

\subsection{Joyce Glacier, Antarctica}

Joyce Glacier $\left(67^{\circ} 06^{\prime} \mathrm{S}, 50^{\circ} 09^{\prime} \mathrm{W} ; 90 \mathrm{~km}^{2}\right)$ is situated in the Garwood Valley, Antarctica. A large proglacial lake, 
dammed by an ice sheet grounded in the McMurdo Sound $>23000{ }^{14}$ C yr BP (Péwé, 1960; Hendy, 2000), is thought to have previously occupied the valley (Hendy, 2000). Joyce Glacier is cold-based, meaning that it is completely frozen to the underlying substrate. The bedrock lithology includes dolomite, granite, and metamorphic rocks. Joyce Glacier recently advanced over lake sediment (Stuiver et al., 1981), and hence the basal material is thought to contain labile OC and algal-derived organic matter of Holocene age.

\subsection{Russell Glacier, GrIS}

Russell Glacier $\left(67^{\circ} 03^{\prime} \mathrm{N}, 50^{\circ} 10^{\prime} \mathrm{W} ;>600 \mathrm{~km}^{2}\right)$, situated on the west margin of the GrIS, is polythermal-based. Warm ice, with a temperature at the pressure melting point, in the interior is surrounded by a frozen layer beneath the thinner ice of the margins. Surface melting delivers supraglacial meltwater to the subglacial system from the onset of the spring thaw. The bedrock is predominantly Archaean gneiss (Escher and Watt, 1976). Basal debris contains overridden Quaternary deposits (including palaeosols) and relatively fresh organic matter (Knight et al., 2002), which was buried during the Holocene (Simpson et al., 2009).

\subsection{Finsterwalderbreen, Svalbard}

Finsterwalderbreen $\left(77^{\circ} 28^{\prime} \mathrm{N}, 15^{\circ} 18^{\prime} \mathrm{E} ; 44 \mathrm{~km}^{2}\right)$ is located on the southern side of Van Keulenfjorden, southern Svalbard, and is a polythermal surge-type glacier. Finsterwalderbreen last surged between 1898 and 1920 (Liestøl, 1999), which may have influenced the formation of the basal ice as has been shown, for example, at Variegated Glacier (Sharp et al., 1994). The glacier is currently retreating at a rate of 10-45 $\mathrm{m} \mathrm{a}^{-1}$ (Wadham et al., 2007). The bedrock consists of Precambrian carbonates, sandstones, limestones, and shales (Dallmann et al., 1990). Shales exposed to water may provide a steady source of DOC (Schillawski and Petsch, 2008). The shale beneath Finsterwalderbreen contains up to $2.3 \%$ OC (Wadham et al., 2004).

\subsection{Engabreen, Norway}

Engabreen $\left(66^{\circ} 41^{\prime} \mathrm{N}, 13^{\circ} 46^{\prime} \mathrm{E} ; 40 \mathrm{~km}^{2}\right)$ is temperate and part of the western Svartisen ice cap, northern Norway. Engabreen bedrock consists mostly of schist and gneiss, with calcite-filled cracks (Jansson et al., 1996), and contains relatively little OC. A combination of in-washed material from the glacier surface and overridden soils of Holocene age may be the principal OC sources (Stibal et al., 2012).

\subsection{Basal ice description and sample collection}

Joyce Glacier basal ice samples were collected in the austral summer of 2010 from recently exposed, upthrust bands of debris-rich basal ice at the margin on the southern flank of the glacier. Basal ice was sampled where the facies were composed of frozen debris and only weakly exhibited layers that were $>1 \mathrm{~mm}$ thick but $<1 \mathrm{~m}$ thick, classified as solid banded basal ice (Hubbard et al., 2009). We assume that the basal ice was formed under cold-based conditions.

Debris-rich basal ice blocks from the Russell Glacier margin were collected in spring 2008. Samples were collected from the southern corner of the glacier where it has previous advanced into a dune and from within $1.5 \mathrm{~m}$ of the ice-bed contact. The basal ice samples contained subglacial sediment that had been extruded up from the glacier bed via fissures near the terminus. This comprised banded basal ice where the debris was generally restricted to narrow sediment layers and large vein networks were clearly evident. As Russell Glacier is polythermal, we assume that the basal ice was formed by a combination of regelation and cold-based processes such as basal adfreezing onto the glacier sole.

Finsterwalderbreen was sampled in autumn 2008. Basal ice blocks were collected from the terminus on the northern flank of the glacier from sections of dispersed banded basal ice (referred to as DB basal ice), within $1.5 \mathrm{~m}$ of the ice-bed contact, and from surface outcrops of frozen subglacial material, or thrust bands, with distinct debris layers (referred to as solid banded (SB) basal ice). It is probable that the thrust bands were formed during the most recent surge during two phases of thrusting: primary thrusting during the early surge phase in the subglacial zone between temperate ice and cold ice, and secondary thrusting during the surge termination due to ice flow compression, as envisaged for the similar polythermal surge-type Kuannersuit Glacier (Larsen et al., 2010). Finsterwalderbreen DB and SB basal ice are reported separately due to the very different mean debris concentrations (by mass): $20 \pm 27 \%$ (DB basal ice) and $86 \pm 6 \%$ (SB basal ice, where the debris component was much higher). As Finsterwalderbreen is polythermal, we assume that the basal ice was formed by a combination of regelation and cold-based processes. Basal ice samples from Finsterwalderbreen and Russell Glacier were collected from the same sites as the samples that were analysed in Stibal et al. (2012), and hence we use their ${ }^{14} \mathrm{C}$ ages (Table 2).

Debris-rich basal ice samples from Engabreen were collected in autumn 2009 from an underground tunnel system excavated through bedrock beneath $210 \mathrm{~m}$ of sliding ice (Cohen, 2000). The basal ice stratigraphy comprises sedimentrich ice layers overlain by clean sediment-free and bubblefree ice (Jansson et al., 1996). We collected samples from sections of banded basal cryofacies from within $1.5 \mathrm{~m}$ of the ice-bed contact. Hot-water drilling was first implemented to create a basal cavity and the ice subsequently extracted by chain-sawing (described below). As Engabreen is temperate, we assume that the basal ice was formed primarily by regelation (Jansson et al., 1996).

Basal ice blocks $\left(\sim 40 \mathrm{~cm}^{3}\right)$ were collected by chainsawing in all sample locations. The outermost $\sim 0.5 \mathrm{~m}$ of the ice surface was removed before the blocks were cut. The blocks were wrapped in pre-combusted foil and stored at 
$\leq-20^{\circ} \mathrm{C}$, before being transported frozen to the University of Bristol and subsequently stored at $\leq-20^{\circ} \mathrm{C}$.

\section{Methodology}

\subsection{Basal ice melt and sediment sample preparation}

Subsamples of the basal ice were prepared for analysis by chipping $\sim 15 \mathrm{~cm}^{3}$ chunks from the main block using a flame sterilized chisel. The outer $\sim 10-30 \mathrm{~mm}$ of the chips was removed by rinsing with ultrapure $(\geq 18.2 \mathrm{M} \Omega \mathrm{cm})$ deionized water (DI) (Millipore), and the remaining ice was transferred into a pre-combusted glass beaker covered with foil. The ice was allowed to melt inside a laminar flow cabinet (Telstar Mini-H) under ambient laboratory conditions, which allowed any sediment to settle out of suspension. The ice melt was then decanted into smaller pre-combusted beakers. Ice melt was filtered through Whatman polypropylene Puradisc ${ }^{\mathrm{TM}} 0.45 \mu \mathrm{m}$ syringe filters. Water samples for subsequent $\mathrm{OC}$ analysis were stored in clean pre-combusted borosilicate glass bottles (thrice rinsed with the sample before storage). Five samples of filtered ice melt were taken from the $\sim 15 \mathrm{~cm}^{3}$ chunks cut out of the Joyce Glacier basal ice block, the Finsterwalderbreen DB ice block, and the Finsterwalderbreen SB ice block. Slightly larger volumes of ice melt permitted six samples of filtered ice melt to be collected from the Engabreen basal ice chunk, and seven from the Russell Glacier chunk. DI procedural blanks $(n=5)$ were subject to identical processing as the samples from the filtration stage onwards to monitor for possible contamination during processing and storage. Sample concentrations were subsequently blank corrected (see Sect. 3.3.4).

Subsamples from each ice block were also collected for free carboxylic acid (FCA) determination. Ice was melted in an inert gas $\left(\mathrm{O}_{2}\right.$-free- $\left.\mathrm{N}_{2}, \mathrm{OFN}\right)$ atmosphere to limit potential contamination during the melting process (Saigne et al., 1987). The OFN gas first travelled through a hydrocarbon trap (HT200-4, Agilent) to remove any volatile OC compounds. Ice melt was filtered through Whatman polypropylene Puradisc ${ }^{\mathrm{TM}} 0.45 \mu \mathrm{m}$ syringe filters into $1.5 \mathrm{~mL}$ vials with PTFE caps (Chromacol). Samples were analysed within $24 \mathrm{~h}$ of melting to minimize losses due to the volatile nature of the FCA compounds. Procedural blanks were collected in concert.

The subglacial sediment OC content was derived from analysis of the settled particles, which were transferred from the beakers with clean, ethanol-rinsed metal spatulas and stored in sterile $0.5 \mathrm{~L}$ Whirl-pak bags (Nasco). Every effort was made to collect as much of the finer sediment as possible from the bottom and sides of the beakers. However, some fine sediment may have remained in the beaker and was thus excluded from the OC determinations. We were also unable to collect the fine particles that remained in suspension owing to the use of syringe filters to filter the ice melt. The to- tal mass of this finer sediment was small compared to the mass of the settled sediment; therefore OC determinations were not unduly compromised. Sediment and filtered samples were stored in the dark at $\leq-20^{\circ} \mathrm{C}$ until analytical processing.

\section{Basal ice debris concentration}

Basal ice debris concentrations (\% by mass) were determined by mass subtraction. Basal ice debris typically comprised sediment particles predominantly $<2 \mathrm{~mm}$ plus some small gravel in the Finsterwalderbreen SB samples. First, the melted basal ice samples (sediment + ice melt) were weighed and the sediment extracted according to the procedure described above. The sediment was dried in a hot-air oven $\left(105^{\circ} \mathrm{C}\right)$ for a minimum of $12 \mathrm{~h}$ and weighed. The basal ice debris concentration was expressed as a percentage of a mass (of sediment) to mass (total mass of ice and sediment) basis.

\subsection{Basal sediment analysis}

\subsubsection{Elemental analysis}

The subglacial sediments were first dried in a hot-air oven $\left(105^{\circ} \mathrm{C}, 12 \mathrm{~h}\right)$ and then manually homogenized by grinding. Total carbon (TC) was measured on an EA1108 Elemental Analyser (EuroVector). Inorganic carbon (InC) was determined by a modified Coulomat 702 Analyser (Ströhlein Instruments). Total OC was calculated as the difference between TC and InC. The precision of determinations was $<5 \%$. Samples were calibrated using external reference standards at a detection limit of $0.1 \mathrm{mg} \mathrm{g}^{-1}$ (or $0.01 \%$ ).

\subsubsection{Carbohydrate sediment extractions}

Previous studies have estimated sediment OC bioavailability based on the concentration of extractable carbohydrates (Biersmith and Benner, 1998; Pusceddu et al., 2009). We employed this method to provide a conservative estimate and acknowledge that this is not a comprehensive assessment of bioavailable $\mathrm{OC}$ in the subglacial material, as other compounds, such as enzymatically hydrolysable amino acids, were not quantified. Operationally defined minimum estimates of extractable carbohydrate concentrations in basal sediment were quantified by ion chromatography following an acid-extraction protocol to convert any polysaccharides and sugar derivatives to lower molecular weight components (Jensen et al., 2005). We followed the protocol described in Stibal et al. (2010) and conducted each extraction procedure in triplicate. Monosaccharide losses occurred during hydrolysis, including the total loss of fructose, and were not compensated for (Borch and Kirchmann, 1997; Jensen et al., 2005). This methodological limitation means that some of the variability between samples will be due to procedural ef- 
fects, rather than a true disparity between sediment carbohydrate concentrations.

\subsubsection{Cell counts}

Cell counts were conducted to quantify the microbial abundance in basal sediment and determine whether there is potential for subglacial microbial activity. We followed the protocol described in Stibal et al. (2012). For Joyce Glacier samples, the method followed that of Porter and Feig (1980) (detailed in the Supplement).

\subsection{Analysis of basal ice melt}

\subsubsection{Bulk DOC}

DOC was determined by high-temperature combustion $\left(680^{\circ} \mathrm{C}\right)$ using a Shimadzu TOC-V $\mathrm{CSN}_{\mathrm{CN}} / \mathrm{TNM}-1$ Analyzer equipped with a high-sensitivity catalyst. Precision and accuracy of standard solutions $(5-170 \mu \mathrm{MC})$ of potassium hydrogen phthalate $\left(\mathrm{C}_{8} \mathrm{H}_{5} \mathrm{KO}_{4}\right)$ (Merck) were $< \pm 6 \%$, and the limit of detection (LOD) was $5 \mu \mathrm{MC}$.

\subsubsection{Fluorescence spectroscopy}

Fluorescence spectra were determined on a HORIBA Jobin Yvon Fluorolog-3 spectrofluorometer equipped with excitation and emission monochromators, a Xenon lamp (excitation source) and FluorEssence Software. Synchronous scans were performed at $1 \mathrm{~nm}$ increments with a $0.1 \mathrm{~s}$ integration period, $10 \mathrm{~nm}$ bandwidth, and an $18 \mathrm{~nm}$ offset between excitation and emission monochromators (Barker et al., 2006). The accuracy of the monochromators was $\pm 0.5 \mathrm{~nm}$. Synchronous scans of DI were run under identical scanning conditions and subtracted from all sample spectra to correct for Raman scattering. All scans were dark corrected and internally corrected for inner filter effects and variations in lamp performance. Post-scan data correction followed the protocol described by Barker et al. (2006). Fluorophore recognition was based on values reported in the literature (Miano and Senesi, 1992; Ferrari and Mingazzini, 1995; Coble, 1996; Yamashita and Tanoue, 2003), and all spectra were normalized to the sample fluorescence peak spectral maximum.

\subsubsection{OC compound determination by ion chromatography}

FAA, carbohydrate (FCHO), and carboxylic acid (FCA) determinations were performed by an ICS-3000 dual-analysis reagent-free ion chromatography system, employing electrolytic $\mathrm{NaOH}$ eluent generation (Dionex ${ }^{\mathrm{TM}}$, part of Thermo Fisher Scientific). Precision and accuracy were monitored by periodically running certified external standards (Dione ${ }^{\mathrm{TM}}$ ), and internal standards during each sample run, at concentrations within the range of sample concentrations (10$2000 \mathrm{nMC}$ ). The limit of quantification (LOQ) was defined as the concentration of the lowest standard that could be significantly differentiated from the next highest. The 28 basal ice samples and five DI blanks were analysed in small batches. To limit any potential change in analyte abundance or composition over the course of the batch analysis due to inorganic or organic activity within the sample vial, we typically ran 8-10 samples (plus standards and DI to flush the system) during each run. Prior to running the samples we assessed the level of drift (which may account for instrumental drift plus changes in LMW-DOC compounds) in a low-level standard $\left(50 \mu \mathrm{g} \mathrm{L}^{-1}\right)$ and found that ca. 21 samples could be run before significant drift (exceeding the precision of the instrument) was noted. Due to the scarcity of sample volume we were unable to explore whether LMW-DOC concentrations in each sample changed over the course of the sample run.

FAAs were separated via gradient anion exchange on an AminoPac PA10 column $(2 \times 250 \mathrm{~mm})$ after passing through an AminoPac PA10 guard column $(2 \times 50 \mathrm{~mm})$. Pulsed electrochemical detection with an Au electrode was employed. A gradient mix of $0.25 \mathrm{M} \mathrm{NaOH}, 1.0 \mathrm{M}$ sodium acetate $(\mathrm{NaOAC})$ and DI was used to elute 14 FAAs (lysine, alanine, threonine, glycine, valine, serine/proline, isoleucine, leucine, methionine, phenylalanine, cysteine, aspartic acid, glutamic acid and tyrosine) at a flow rate of $0.25 \mathrm{~mL} \mathrm{~min}^{-1}$. Serine and proline were reported together due to co-elution. Precision was typically ca. $\pm 5 \%$ for lysine, alanine, threonine, glycine, valine, serine/proline, isoleucine, leucine, methionine, and cysteine, and ca. $\pm 10 \%$ for phenylalanine, aspartic acid, glutamic acid and tyrosine. Accuracy was $< \pm 7 \%$ for all analytes (certified external standard, Fluka Analytical). The LOQ ranged from 10 to $60 \mathrm{nMC}$.

FCHOs - fucose, rhamnose, arabinose, galactose, glucose, xylose/mannose, fructose/sucrose, ribose, and lactose - were separated isocratically at a flow rate of $0.35 \mathrm{~mL} \mathrm{~min}^{-1}$ on a CarboPac PA20 column $(3 \times 150 \mathrm{~mm})$ after passing through a CarboPac PA20 guard column $(3 \times 30 \mathrm{~mm})$. Xylose and mannose, and fructose and sucrose, were reported together due to co-elution. Precision for fucose, rhamnose, arabinose, glucose, and xylose/mannose was generally ca. $\pm 5 \%$, and ca. $\pm 10 \%$ for galactose, fructose/sucrose, ribose, and lactose. Accuracy of a certified external standard (Dionex ${ }^{\mathrm{TM}}$ ) was $< \pm 7 \%$ for all analytes. The LOQ ranged from 10 to $80 \mathrm{nMC}$.

FCAs - acetate, formate, propionate, and butyrate were separated via gradient anion exchange on an IonPac Hydroxide-Selective Anion Exchange AS11-HC column $(2 \times 250 \mathrm{~mm})$ with an AS11-HC guard column $(2 \times$ $50 \mathrm{~mm}$ ) and Anion Self-Regenerating Suppressor (ASRS). Electrolytic eluent generation was employed to allow analyte separation along a $\mathrm{NaOH}$ gradient during the 30 min run at a flow rate of $0.5 \mathrm{~mL} \mathrm{~min}^{-1}$. Precision and accuracy of the four FCAs in a certified reference standard (Supelco Analytical) were 5-8\% and 3-4\%, respectively. The LOQ ranged from 90 to $130 \mathrm{nMC}$. 


\subsubsection{Blank corrections}

Preparation of DI blanks is described in Sect. 3.1. Blank corrections were not required for FAAs due to the negligible blank concentrations. Minimal corrections were required for FCHOs $(1.3 \mathrm{nMC})$, but larger corrections were required for DOC $(5.85 \mu \mathrm{MC})$ and FCAs $(23.06 \mathrm{nMC})$.

\section{Results}

\subsection{Basal sediment characteristics}

Basal ice debris concentrations (by mass) differed between glaciers. Finsterwalderbreen solid banded (FSB) and Russell Glacier basal ice contained the highest concentration of debris ( $86 \pm 7$ and $55 \pm 25 \%$, Table 1), which are similar to percentages in GrIS banded ice (46-57\%), solid ice $(61 \%)$ (Yde et al., 2010), and debris bands (71\%) (Sugden et al., 1987). Debris concentrations in basal ice from Engabreen $(37 \pm 21 \%)$, Joyce Glacier $(21 \pm 6 \%)$, and Finsterwalderbreen dispersed banded (FDB) $(20 \pm 27 \%)$ were lower than percentages in GrIS and FSB ice.

We investigated possible correlations between DOC (and LMW-DOC) and the debris content of the basal ice, which may provide information on DOC provenance and the potential for DOC to leach from sediments into the basal ice. We acknowledge that if DOC is leached from sediments the controlling variable will be the surface area, rather than the debris concentration. However, a detailed investigation into the particle size distribution was beyond the scope of this study. We thus conducted a preliminary analysis to determine if the relationship with debris concentration differed for DOC and LMW-DOC. Significant positive associations between debris concentration and DOC were only evident in Joyce Glacier $\left(R^{2}=0.71, p<0.05\right)$ and Russell Glacier $\left(R^{2}=0.72, p<0.05\right)$ basal ice (Fig. 1a). No significant associations between LMW-DOC and debris concentrations were observed (Fig. 1b, $R^{2}<0.1, p<0.05$ ).

The sediment OC content was low $(<0.6 \%)$ in all basal ice samples (Table 2). Minor fractions of extractable carbohydrate $(<0.5 \%$ of the sediment OC) were measured in Engabreen, Russell Glacier, and Finsterwalderbreen sediments. A higher carbohydrate fraction (17\% of the sediment OC) was measured at Joyce Glacier (Table 2). We use this as a proxy for lability (Biersmith and Benner, 1998; Pusceddu et al., 2009) and thus make the assumption that Joyce Glacier sediment is bioavailable. Microbial cell abundance was comparable in all samples $\left(1-7 \times 10^{5}\right.$ cells g $^{-1}$, Table 2$)$.

\subsection{Subglacial DOC quantity and complexity}

DOC abundance and composition varied between the four glaciers. The highest mean DOC concentrations were observed in basal ice from Joyce Glacier $(272 \pm 99 \mu \mathrm{MC})$, and Engabreen $(114 \pm 106 \mu \mathrm{MC})$, with lower concentrations in
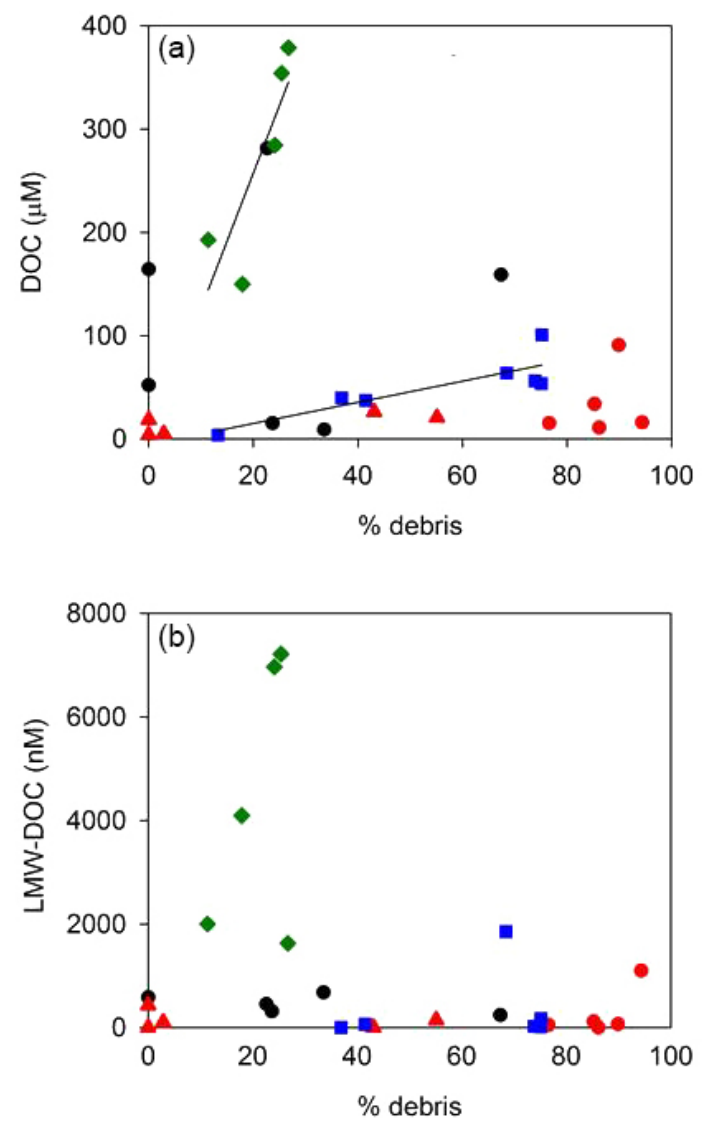

Figure 1. Associations between (a) DOC and debris concentration, and (b) LMW-DOC and debris concentration. Engabreen samples are given in black, Finsterwalderbreen in red (FDB (dispersed banded ice) as triangles and FSB (solid banded ice) as circles), Russell Glacier in blue, and Joyce Glacier in green. $P<0.05$ for all regression equations, only significant correlations are shown.

Russell Glacier basal ice $(53 \pm 29 \mu \mathrm{M} \mathrm{C})$, FDB $(15 \pm 10 \mu \mathrm{M} \mathrm{C})$ and FSB $(33 \pm 33 \mu \mathrm{MC})$ (Table 1). The relatively large standard deviations show that subglacial DOC concentrations are highly variable, even in basal ice from the same glacier. Between five and seven replicate samples were taken from each of the $\sim 15 \mathrm{~cm}^{3}$ chunks cut out of the main ice blocks from each glacier (detailed in Sect. 3.1). The variability in the DOC concentrations suggests that there is significant spatial heterogeneity even at the level of the $\sim 15 \mathrm{~cm}^{3}$ basal ice chunks analysed from each glacier.

The composition of the subglacial DOC was investigated by spectrofluorescence and ion chromatography. The synchronous fluorescence spectra of all basal ice samples illustrated the dominance of three key fluorophores of a marine humic-like/fulvic acid type, at ca. 340, 385, and $440 \mathrm{~nm}$ (excitation wavelengths, Fig. 2, Table 3), and several unresolved fluorophores at longer excitation wavelengths. Protein-like peaks ( $\sim 279 \mathrm{~nm}$ excitation wavelength), indicative of tyrosine-like compounds (Ferrari and Mingazzini, 
Table 1. Biogeochemical data for basal ice from Engabreen (E), Finsterwalderbreen (F), Russell Glacier (R), and Joyce Glacier (J). DB indicates dispersed banded and SB solid banded. Values given are the mean concentrations for each analyte, and the standard deviation is given in parentheses. LMW-DOC is free carbohydrates (FCHOs) + free amino acids (FAAs) + free carboxylic acids (FCAs). Only values $>$ LOQ have been included.

\begin{tabular}{lllllll}
\hline Sample & \% debris (by mass) & DOC $(\mu \mathrm{M} \mathrm{C})$ & LMW DOC $(\mathrm{nM} \mathrm{C})$ & FCHOs $(\mathrm{nM} \mathrm{C})$ & FAAs $(\mathrm{nM} \mathrm{C})$ & FCAs $(\mathrm{nM} \mathrm{C})$ \\
\hline E $(n=6)$ & $36.83(20.96)$ & $113.56(106.60)$ & $417.70(213.07)$ & 0.00 & $22.41(24.24)$ & $442.19(164.00)$ \\
FDB $(n=5)$ & $20.22(26.74)$ & $14.85(9.91)$ & $169.67(183.90)$ & 0.00 & 0.00 & $169.67(183.90)$ \\
FSB $(n=5)$ & $86.47(6.58)$ & $33.38(33.30)$ & $312.67(502.64)$ & 0.00 & $46.47(48.99)$ & $274.91(549.83)$ \\
R $(n=7)$ & $54.89(24.51)$ & $53.31(28.89)$ & $343.72(689.83)$ & 0.00 & $50.59(62.97)$ & $365.62(817.56)$ \\
J $(n=5)$ & $21.22(6.41)$ & $272.09(99.38)$ & $4429.83(2625.95)$ & $28.29(15.83)$ & $4353.30(2643.59)$ & 0.00 \\
\hline
\end{tabular}

Table 2. Mean sediment characteristics. An asterisk indicates sediment OC age from Stibal et al. (2012), method described in the online supporting information. ND denotes not determined. E - Engabreen, F - Finsterwalderbreen, R - Russell Glacier, J - Joyce Glacier. Standard deviation is given in parentheses.

\begin{tabular}{lllllll}
\hline Sample & $\begin{array}{l}{ }^{14} \mathrm{C} \text { age } \\
(\text { years, BP)* }\end{array}$ & $\% \mathrm{OC}$ & $\% \mathrm{InC}$ & $\begin{array}{l}\text { Extractable } \\
\text { carbohydrates } \\
\left(\mu \mathrm{g} \mathrm{g}^{-1}\right)\end{array}$ & $\begin{array}{l}\text { Carbohydrate } \\
\text { fraction } \\
(\% \text { of OC) })^{*}\end{array}$ & $\begin{array}{l}\text { Cell } \\
\text { abundance } \\
\left(\mathrm{cell} \mathrm{g}^{-1}\right)\end{array}$ \\
\hline $\mathrm{E}(n=5)$ & $\mathrm{ND}$ & $0.19(0.08)$ & $0.24(0.18)$ & 3.26 & 0.17 & $6.80 \times 10^{5}$ \\
$\mathrm{~F}(n=5)$ & $3750(150)$ & $0.57(0.12)$ & $1.80(0.25)$ & 2.34 & 0.04 & $1.68 \times 10^{5}$ \\
$\mathrm{R}(n=5)$ & $1830(50)$ & $0.44(0.09)$ & $0.01(0.00)$ & 20.83 & 0.47 & $2.26 \times 10^{5}$ \\
$\mathrm{~J}(n=5)$ & $\mathrm{ND}$ & $0.01(0.02)$ & $0.28(0.05)$ & 23.95 & 17.11 & $1.16 \times 10^{5}$ \\
\hline
\end{tabular}

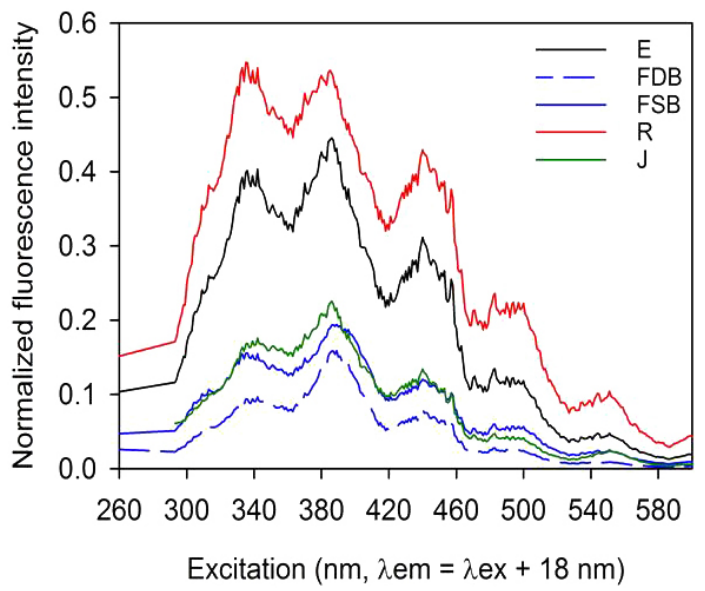

Figure 2. Mean normalized synchronous fluorescence spectra for basal ice samples. E - Engabreen, F - Finsterwalderbreen, R - Russell Glacier, J - Joyce Glacier, DB - dispersed banded, SB - solid banded.

1995; Yamashita and Tanoue, 2003), were only evident in Joyce Glacier and FSB basal ice (Table 3). Ion chromatographic analyses provided a greater level of detail on the molecular composition of the DOC. LMW-DOC compounds, with concentrations $>\mathrm{LOQ}$, accounted for $<3 \%$ of the DOC in all basal ice samples. Mean LMW-DOC concentrations in Engabreen, Finsterwalderbreen, and Russell Glacier basal ice were $<420 \mathrm{nMC}$ (Table 1). Mean LMW-DOC concentrations were an order of magnitude higher $(4430 \mathrm{nMC})$ in
Joyce Glacier basal ice. As with DOC concentrations, the variability in the LMW-DOC compound concentrations suggests high spatial heterogeneity within the basal ice.

LMW-DOC was typically dominated by FCAs (Table 1), except in Joyce Glacier samples, which are subsequently discussed. Overall, acetate was the most common analyte (Fig. 3), being present in $60 \%$ of the samples that contained FCAs at concentrations $>$ LOQ. Basal ice FCHO concentrations were typically $<$ LOQ $(<4 \%$ of the LMW-DOC, Table 1) and only detected in Joyce Glacier samples, comprising glucose (16-49 nMC) and ribose (16-19 nMC, data not shown). Joyce Glacier basal ice DOC was unique in that most $(98 \%)$ of the LMW-DOC was derived from the extremely diverse FAA pool (Fig. 4). Mean FAA concentration in Joyce Glacier basal ice $(4353 \pm 2643 \mathrm{nMC})$ was an order of magnitude higher than mean FAA concentrations in Engabreen, Finsterwalderbreen, and Russell Glacier basal ice (0-51 nM C, Table 1). Some 14 FAAs were detected in Joyce Glacier basal ice, including methionine, glutamic acid, aspartic acid and cysteine, which were not observed in the other basal ice samples. Serine/proline, alanine, and valine dominated the Joyce Glacier FAA pool. FAAs accounted for $59 \%$ of the LMW-DOC in Russell Glacier basal and FSB ice, primarily in the form of alanine and valine, respectively.

\section{Discussion}

The application of a novel methodological approach (within the field of glacial science) using ion chromatography has 
Table 3. Summary of the dominant fluorophores in basal ice from four contrasting glacial environments. The dominant fluorophores (denoted by an asterisk) have been identified according to previous characterization of spectral compounds (see Barker et al., 2009, and references therein). DB - dispersed banded, SB - solid banded.

\begin{tabular}{lllc}
\hline Sample & Fluorophore (peak excitation wavelength, nm) & Dominant fluorophore identification & $n$ \\
\hline Engabreen & $342,386^{*}, 440,483$ & Fulvic acid, marine humic-like & 6 \\
Finsterwalderbreen DB & $342,389^{*}, 440$ & Fulvic acid, marine humic-like & 5 \\
Finsterwalderbreen SB & $276,336,389^{*}, 440$ & Fulvic acid, marine humic-like & 5 \\
Russell Glacier & $335^{*}, 385,440,483$ & Protein-like/marine humic-like & 7 \\
Joyce Glacier & $279,342,386^{*}, 440,460,551$ & Fulvic acid, marine humic-like & 5 \\
\hline
\end{tabular}

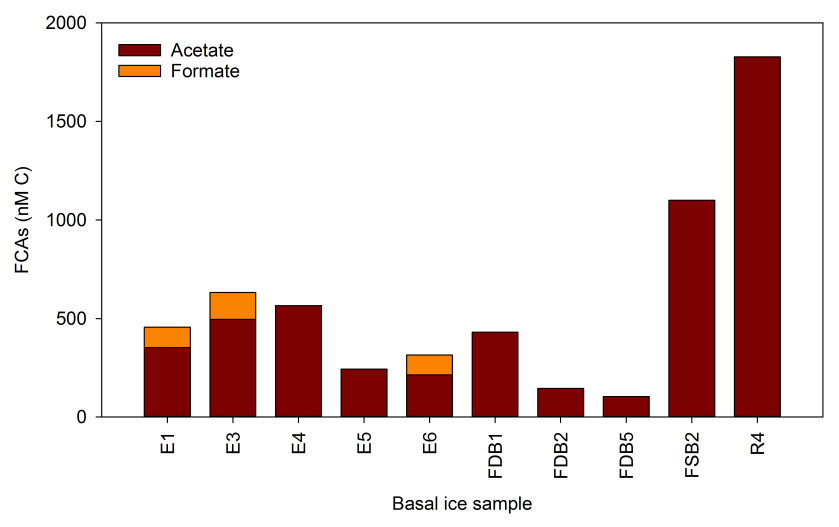

Figure 3. FCA compositions in basal ice samples. E - Engabreen, F - Finsterwalderbreen, R - Russell Glacier, DB - dispersed banded, $\mathrm{SB}$ - solid banded. Samples with zero concentrations have been excluded from the plot, and only values > LOQ have been included.

allowed the identification and quantification of a range of LMW-DOC compounds in debris-rich basal ice, including FCAs, FCHOs, and FAAs, at unprecedented low concentrations ( $<70 \mathrm{nM} \mathrm{C})$. This represents, to our knowledge, the first study to quantify LMW-DOC in basal ice from a range of glaciers and ice sheets. We demonstrate that ion chromatographic systems that have been optimized for the detection of trace-level LMW-DOC concentrations (e.g. by using multiple eluents, low flow rates, and gradient elution) can be utilized as an additional quantitative technique to supplement characterizations of glacial LMW-DOC by ESI FT-ICR MS (Grannas et al., 2006; Bhatia et al., 2010; Lawson et al., 2014a) and solution-state ${ }^{1} \mathrm{H}$ NMR spectroscopy (Pautler et al., 2011, 2012).

\subsection{The influence of debris type on sediment $\mathrm{OC}$ and basal ice DOC concentrations}

We find little evidence that the type of overridden material (i.e. the pre-entrainment sedimentary type such as lacustrine material or palaeosols) and the mean sediment OC content has a significant influence on the DOC content in basal ice. Indeed, the mean basal ice DOC concentrations (Table 1) and mean sediment OC content (Table 2) were relatively similar
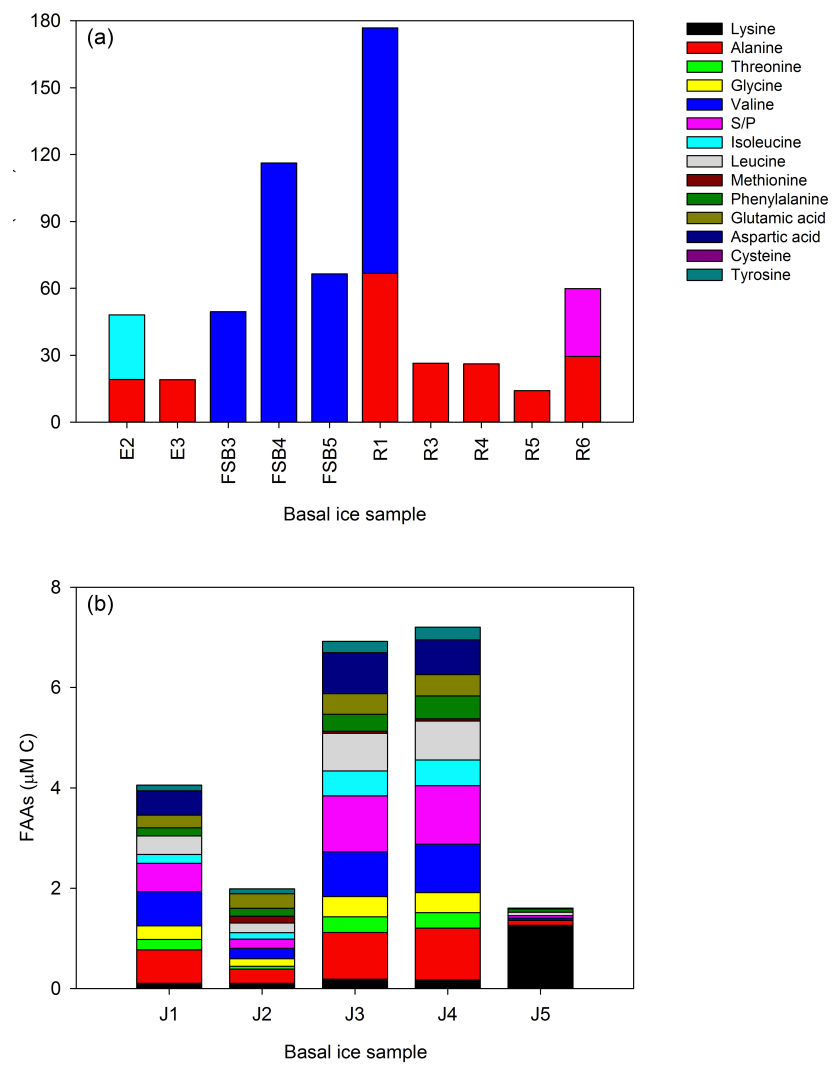

Figure 4. FAA composition in basal ice samples from (a) Engabreen (E), Finsterwalderbreen (F), Russell Glacier (R), and Joyce Glacier (J), (b) FAAs in Joyce Glacier basal ice, plotted separately due to an order of magnitude increase in concentrations. Samples with zero concentrations have been excluded from the plot, and only values $>$ LOQ have been included. S/P - serine and proline, reported together due to co-elution. SB - solid banded.

in all basal ice samples despite the differences in the types of overridden material. Furthermore, the fact that the highest mean DOC concentration was observed in Joyce Glacier basal ice $(272 \mu \mathrm{MC})$ yet the corresponding sediment OC \% was the lowest $(0.01 \%)$ of all four sites demonstrates the lack of a relationship between sediment OC \% and basal ice DOC. This may be due to the particular section of basal sediment that was sampled as, in the case of Joyce Glacier, higher OC 
content has previously been observed in other Antarctic lacustrine samples, such as subglacial sediment beneath Lower Wright Glacier (0.7\% OC) (Stibal et al., 2012), and Antarctic Dry Valley lacustrine sediments containing microbial mats ( $9 \%$ OC) (Squyres et al., 1991). This suggests a more diverse basal sediment matrix comprising algal mats and organic lacustrine material that mixed with sand and/or other low-OC, mineral-based material during basal ice formation beneath Joyce Glacier. However, we acknowledge that some of the difference in sediment OC (and extractable carbohydrate concentrations) may be due to the different analytical methods employed in this and previous studies. The concentrations that we present may also be conservative as our methodological approach meant that fine-sediment fractions, which may be OC-rich, remained in suspension and were not included in the OC determinations.

Key differences were, however, observed in the proportions of extractable carbohydrates (a proxy for bioavailable compounds in the basal sediment) and LMW-DOC concentrations in basal ice from the four sites. The LMW-DOC concentrations in Joyce Glacier basal ice, which were an order of magnitude higher than LMW-DOC concentrations in samples from the other three sites and predominantly due to high FAA concentrations, may have derived from the relatively large pool of potentially bioreactive extractable carbohydrates in Joyce Glacier basal sediment (17\% of the sediment OC, compared with $<0.5 \%$ of the sediment OC in samples from Russell Glacier, Engabreen, and Finsterwalderbreen). The bioreactive OC pool in Joyce Glacier basal sediment may have been enhanced by the assimilation of proglacial algal mats into overridden material during glacial advance, which likely enriched the basal ice with lacustrine material and associated algal necromass (Pautler et al., 2012), which may include autochthonous material produced by microorganisms prior to basal ice formation. Indeed, lacustrine material is generally acknowledged as a source of reactive OC to microorganisms (Meyers and Ishiwatari, 1993). The lower extractable carbohydrate concentrations in basal sediment from Russell Glacier, Engabreen, and Finsterwalderbreen (compared with Joyce Glacier) are thought to reflect the more refractory nature of the overridden material. OC in subglacial material beneath this sampled section of Russell Glacier is thought to derive from a soil origin, based on relatively high concentrations of $n$-alkanoic acids, steroids, and other soil-derived functional compounds that have been identified in basal ice samples (Stibal et al., 2012). Due to this, and the relatively young age of Russell Glacier sediment OC $\left(<1900{ }^{14} \mathrm{C}\right.$ yr BP $)$, we expected the total and bioreactive $\mathrm{OC}$ concentrations to be higher than 0.44 and $0.47 \%$ of the OC, respectively. For instance, OC content in Greenland soils range from 0.1 to $44.8 \%$ in C horizons and peat soils (Horwath Burnham and Slettern, 2010). The low OC and extractable carbohydrate concentrations in Russell Glacier basal ice may reflect a heterogeneous sediment matrix that incorporates a lower proportion of palaeosols mixed with other low-OC, mineral-based material. However, as discussed earlier, these differences in sediment OC concentrations may be due to the conservative nature of our methodological approach that may have excluded the potentially OC-rich fine-sediment fractions. The low extractable carbohydrate concentration $(0.04 \%$ of the OC) in Finsterwalderbreen basal sediment is likely influenced by the predominance of OC from kerogen in the overridden shale bedrock (Wadham et al., 2004) that has been incorporated into the basal ice matrix. Kerogen is ancient carbon comprising stable carbon macromolecules and has limited bioreactivity. Similarly, low bioreactive OC in Engabreen basal sediment $(0.17 \%$ of the OC comprised extractable carbohydrates) is influenced by the subglacial substrate comprising overridden continental shield rock depleted in reactive OC, the limited opportunity for material from supraglacial environments to be in-washed, and the limited input of overridden palaeosols (Stibal et al., 2012). A lack of organic biomarkers (derived from algal and higher plant inputs) in Engabreen basal ice further suggests that incorporation of organic material is probably limited (Stibal et al., 2012). Alternatively, the lack of organic biomarkers may be due to debris entrainment by regelation rather than a freeze-on (adfreezing).

In summary, our data suggest that where glaciers and ice sheets override lacustrine sediments, there is an injection of particulate and dissolved bioavailable compounds into the basal ice at the glacier bed, which is less evident where the glacier overrode palaeosols or bedrock. This has implications for subglacial LMW-DOC cycling as this abiotic input of LMW-DOC (via leaching) has the potential to stimulate microbial activity in wet sediments in the subglacial environment. We go on to investigate the DOC and LMW-DOC signatures in basal ice from these contrasting subglacial environments.

\subsection{Basal ice LMW-DOC signatures and provenance}

The presence of LMW-DOC compounds and the similarities in the types of compounds detected in basal ice samples from the four sites may reflect common sources and pathways of transformation of DOC in subglacial environments beneath glaciers and ice sheets. The potential for interactions between basal sediment and subglacial ice melt suggests that inputs from the overridden subglacial material may represent a key contribution to basal ice DOC. The chemical composition of basal ice, including DOC compounds, should reflect characteristics of the parent water prior to being frozen (Knight, 1997), where this water might be either flowing at the base of the glacier, held in porewaters in overridden water-saturated sediment, or refrozen water from pressure melting during the regelation process. These water sources have extensive contact with the subglacial material and so have the potential to acquire dissolved compounds via biogeochemical interactions. However, these processes are highly site specific. Where there are well-developed quick- 
flow components and scoured bedrock channels, for instance, there will be less scope for fast-flowing waters to acquire dissolved compounds from biogeochemical interactions with the overridden material. DOC and LMW-DOC components in basal ice may also be acquired by in situ abiotic processes, e.g. by reactions, such as dissolution, in water films around debris and in liquid water veins (Mader et al., 2006). It is likely that certain organic compounds will remain associated with the debris and others will dissociate to become DOC. To fully assess whether DOC is largely terrestrially derived and leached from sediments, we would need data on the surface area of the debris and information on particle size distribution. As this was beyond the scope of this study we instead used debris concentrations for a preliminary investigation. We find that for sites where there is a bioavailable OC source in sediments (Joyce Glacier) there is a significant relationship between DOC and debris concentration (Fig. 1a). This suggests that subglacial meltwater contact with subglacial sediment beneath Joyce Glacier, which is cold-based and so has little supraglacial meltwater penetration to the glacier bed, is a major control on DOC acquisition. We find several additional lines of evidence to support the leaching of DOC from subglacial sediments, including the presence of fulvic acids that have previously been associated with terrestrial material $(>440 \mathrm{~nm}$ fluorescence wavelengths) in all basal ice samples (McKnight et al., 2001). The basal ice LMW-DOC compounds may also be a leached relic of the overridden material that has been preserved in the ice when frozen. However, the lack of significant association between LMW-DOC and debris concentration (Fig. 1b) is reflective of additional sources and sinks of these compounds in the basal ice layer and/or in the parent water body from which basal ice formed. The LMW-DOC signature in basal ice may also be influenced by in situ microbial production and consumption, as illustrated in earlier work that has proposed a range of microbial processes to be active in the subglacial environment, including in situ chemoautotrophic production (Bhatia et al., 2006, 2013), chemoheterotrophic oxidation of OC substrates to protein-like LMW-DOC compounds (Bhatia et al., 2010), and release of LMW-DOC from decaying cells. It is probable that subglacial microbial activity cycles LMW-DOC both before and after the formation of basal ice. For instance, microorganisms in subglacial sediment porewaters and basal meltwater flowing at the rockwater interface may actively utilize OC substrates and energy sources derived from the overridden material. Via this activity, they may also go on to produce simple LMW-DOC compounds, which may subsequently be incorporated into basal ice. The protein-like peaks that were observed in the spectrofluorescence spectra in Joyce Glacier and FSB ice (Table 3) tentatively suggest that some of the LMW-DOC is of a microbial provenance. Protein-like fluorescence is linked with recent biological activity (De Souza Sierra et al., 1994) and is associated with active FAA production during microbial metabolism (Yamashita and Tanoue, 2003). The finding that FSB samples contained larger protein-like peaks and had higher mean FCA and FAA concentrations when compared with FDB samples may be explained by the different basal ice formation processes at Finsterwalderbreen. FSB debris, sampled from surface outcrops of frozen subglacial material, or thrust bands, is expected to derive from further upglacier than FDB debris and likely formed during the most recent surge ca. 1898-1920 (Liestøl, 1969). This suggests that FSB debris may have been glacier-covered for a much longer period than FDB debris. These conditions may have led to enhanced leaching of LMW-DOC from the subglacial material and/or greater production (vs. consumption) of LMW-DOC by in situ microorganisms. It is also possible that LMWDOC in basal ice from the polythermal and warm-based glaciers sampled in this study (Finsterwalderbreen, Russell Glacier, and Engabreen) could derive from supraglacial inputs as glacially overridden material is not the sole source of DOC in basal ice.

In this study, we were not able to categorically separate LMW-DOC derived from biotic and abiotic processes as, at a molecular level, many LMW-DOC compounds are non-specific biomarkers due to their pervasive occurrence in plants and microorganisms (Biersmith and Benner, 1998). For example, valine, a common FAA in most basal ice samples, can be synthesized in plants via several steps starting from pyruvic acid (e.g. described in Singh, 1999). Valine can also be microbially synthesized from pyruvate (Blombach et al., 2007) and produced by aerobic Gram-positive microbes (Valle et al., 2008). Similarly, glucose can be produced by photosynthesis (Kirchman et al., 2001) and chemoautotrophic bacterial activity (Jansen et al., 1982). The key point is that the presence of numerous LMW-DOC compounds in basal ice from all four glacial sites provides evidence that viable substrates for microbial growth, whether derived from a terrestrial or microbial source, are available in subglacial environments. These LMW-DOC compounds may help support microbial communities within the presentday basal ice, e.g. beneath Russell Glacier, where recent work has shown that the basal ice may be microbially active in the current frozen state (Yde et al., 2010). The microbial cell counts observed in all basal ice samples in this study $\left(10^{5}\right.$ cells $\mathrm{g}^{-1}$, Table 2$)$ are comparable to microbial populations $\left(10^{5}-10^{8}\right.$ cells $\left.^{-1}\right)$ reported in other subglacial sediments that have been proven to be microbially active (Sharp et al., 1999; Foght et al., 2004; Kastovska et al., 2007; Yde et al., 2010; Montross et al., 2012).

\subsection{Implications for LMW-DOC cycling beneath glaciers with bioreactive subglacial sediment}

The margin of Joyce Glacier rests upon ancient lake sediments and, hence, represents a case where a very labile organic matter source is overridden. This situation may have been common in past periods of glaciation, when, for example, the Pleistocene ice sheets advanced over regions with 
a high density of lakes, such as in northern Canada and Scandinavia (Wadham et al., 2008). Hence, the potential for LMW-DOC incorporation in Joyce Glacier basal ice and sediment may be applicable to these other types of lacustrinebased subglacial ecosystems. In addition, the abundance of LMW-DOC in Joyce Glacier suggests that overridden lacustrine material can be sequestered even if the glacier is coldbased. Contrary to traditional assumptions that drainage in cold-based glaciers is entirely supraglacial, it is possible that discrete subglacial channels exist where water is in contact with the substrate, e.g. at Longyearbreen (Yde et al., 2008). This mechanism may enable the release of DOC to downstream ecosystems. If the glacier were warm-based, then the DOC could be flushed out during the summer melt seasons and contribute to the net export of bioavailable DOC to downstream environments. DOC in glacial runoff may derive from multiple sources: terrestrial DOC derived from overridden material at the bed (Hood et al., 2009), anthropogenic aerosol deposition on the glacier surface (Stubbins et al., 2012), and biological activity in both supraglacial (Anesio et al., 2009) and subglacial (Bhatia et al., 2013) environments. The contribution from basal ice may be more significant in cold-based glacier systems, e.g. in the Antarctic Dry Valleys, where daily radiation melting of the steep ice cliffs may release solute from the debris-rich basal ice that is exposed on the cliffs. The distributed drainage system beneath temperate and polythermal glaciers may also include a constant source of water from basal ice melt and groundwater in contact with glacial till (Paterson, 1999).

The dramatic difference in the DOC composition beneath glaciers resting on different $\mathrm{OC}$ substrates that our data have highlighted may have implications for the rate and degree to which this overridden OC can be cycled to biogenic gases in current subglacial environments, which in turn has relevance for the global carbon cycle (Wadham et al., 2008; Stibal et al., 2012). While the DOC and LMW-DOC signatures of basal ice may arise from several confounding factors which are difficult to disentangle, identifying the abundance and composition of DOC in basal ice is an important first step to understanding LMW-DOC cycling in subglacial environments.

\section{Conclusions}

We employ a combined spectrofluorometric and ion chromatographic methodological approach to produce the first identification and quantification, at trace-level concentrations, of major LMW-DOC fractions (free amino acids, carbohydrates, and carboxylic acids) in debris-rich basal ice. We demonstrate that ion chromatographic systems that are optimized for trace-level LMW-DOC analyte detection can supplement traditional methods of LMW-DOC characterization as a quantitative technique. Our work adds to the growing body of research addressing sources and reactivity of DOC in subglacial ecosystems and provides a characterization of
LMW-DOC in basal ice from four different glacial environments with distinctive basal debris types including lacustrine material (Joyce Glacier), overridden soils and tundra (Russell Glacier), kerogen in bedrock (Finsterwalderbreen), and bedrock/soils (Engabreen). We infer that terrestrial inputs from the overridden subglacial material represent a key contribution to basal ice DOC. Our data show that LMW-DOC concentrations in basal ice are dependent on the bioavailability of the overridden OC, which in turn is influenced by the type of overridden material. We find that where glaciers and ice sheets override lakes, such as at Joyce Glacier, there is an injection of particulate and dissolved bioavailable compounds into the basal ice at the glacier bed, which is less evident where glaciers overrode palaeosols or bedrock. There is also potential for the overridden substrate to act as an indirect (via microbial cycling) source of DOC, as the leached LMW-DOC compounds may stimulate microbial activity in wet sediments in the subglacial environment. This has implications for the cycling of overridden OC to biogenic gases in subglacial environments and concurs with recent findings that accelerated melting of glaciers and ice sheets could constitute a significant source of DOC and other, potentially bioavailable dissolved organic matter, to glacially fed ecosystems. The abundance of LMW-DOC in Joyce Glacier basal ice suggests that overridden material may be sequestered even if the glacier is cold-based. Identifying the abundance and composition of DOC in basal ice is an important first step to understanding LMW-DOC cycling in subglacial environments, which has relevance for local carbon cycling and wider ecosystem processes.

\section{The Supplement related to this article is available online at doi:10.5194/bg-13-3833-2016-supplement.}

Author contributions. Jemma L. Wadham and Martyn Tranter conceived the project. Emily C. O'Donnell, Jemma L. Wadham, Grzegorz P. Lis, Marek Stibal, and Sean Fitzsimons collected field data. Emily C. O’Donnell, Grzegorz P. Lis, Amy E. Pickard, and Marek Stibal undertook the lab analysis. Paul Dewsbury, Grzegorz P. Lis, and Emily C. O'Donnell assisted with the Dionex ${ }^{\text {TM }}$ ICS-3000 ion chromatography system optimization and method development. Emily C. O'Donnell, Jemma L. Wadham, and Martyn Tranter wrote the paper with additional comments from the coauthors.

Acknowledgements. This research was funded by the Natural Environment Research Council (UK - NERC grant NE/E004016/1), a NERC CASE studentship to Emily C. O'Donnell (neé Lawson) (NERC DTG/GEOG SN1316.6525), co-sponsored by Dionex Corporation (now part of Thermo Fisher Scientific). Support to Jemma L. Wadham was also provided by the Leverhulme Trust 
via a Philip Leverhulme Prize and a Leverhulme Trust Research Fellowship. We thank Jon Telling for laboratory assistance and are grateful to everyone who helped with basal ice sample collection.

Edited by: X. Wang

\section{References}

Anesio, A. M., Hodson, A. J., Fritz, A., Psenner, R., and Sattler, B.: High microbial activity on glaciers: importance to the global carbon cycle, Global Change Biol., 15, 955-960, doi:10.1111/j.1365-2486.2008.01758.x, 2009.

Barker, J. D., Sharp, M. J., Fitzsimons, S. J., and Turner, R. J.: Abundance and dynamics of dissolved organic carbon in glacier systems, Arct. Antarct. Alp. Res., 38, 163172, doi:10.1657/1523-0430(2006)38[163:AADODO]2.0.CO;2, 2006.

Barker, J. D., Sharp, M. J., and Turner, R. J.: Using synchronous fluorescence spectroscopy and principal component analysis to monitor dissolved organic matter dynamics in a glacier system, Hydrol. Process., 23, 1487-1500, doi:10.1002/hyp.7274, 2009.

Barker, J. D., Klassen, J., Sharp, M. J., Fitzsimons, S. J., and Turner, R. J.: Detecting biogeochemical activity in basal ice using fluorescence spectroscopy, Ann. Glaciol., 51, 47-55, doi:10.3189/172756411795931967, 2010.

Bhatia, M., Sharp, M., and Foght, J.: Distinct bacterial communities exist beneath a high arctic polythermal glacier, Appl. Environ. Microbiol., 72, 5838-5845, doi:10.1128/AEM.00595-06, 2006.

Bhatia, M., Das, S., Longnecker, K., Charette, M., and Kujawinski, E.: Molecular characterization of dissolved organic matter associated with the Greenland ice sheet, Geochim. Cosmochim. Acta, 74, 3768-3784, doi:10.1016/j.gca.2010.03.035, 2010.

Bhatia, M. P., Das, S. B., Xu, L., Charette, M. A., Wadham, J. L., and Kujawinski, E. B.: Organic carbon export from the Greenland ice sheet, Geochim. Cosmochim. Acta, 109, 329-344, doi:10.1016/j.gca.2013.02.006, 2013.

Biersmith, A. and Benner, R.: Carbohydrates in phytoplankton and freshly produced dissolved organic matter, Mar. Chem., 63, 131144, 1998.

Blombach, B., Schreiner, M. E., Holatko, J., Bartek, T., Oldiges, M., and Eikmanns, B. J.: L-Valine production with pyruvate dehydrogenase complex-deficient Corynebacterium glutamicum, Appl. Environ. Microbiol., 73, 2079-2084, doi:10.1128/AEM.0282606, 2007.

Borch, N. H. and Kirchmann, D. L.: Concentration and composition of dissolved combined neutral sugars (polysaccharides) in seawater determined by HPLC-PAD, Mar. Chem., 57, 85-95, doi:10.1016/S0304-4203(97)00002-9, 1997.

Coble, P. G.: Characterization of marine and terrestrial DOM in seawater using excitation emission matrix spectroscopy, Mar. Chem., 51, 325-346, doi:10.1016/0304-4203(95)00062-3, 1996.

Cohen, D.: Rheology of ice at the bed of Engabreen, Norway, J. Glaciol., 46, 611-621, 2000.

Dallmann, W., Hjelle, A., Ohta, Y., Salvigsen, O., Bjørnerud, M., Hauser, E., Maher, H., and Craddock, C.: Geological Map Svalbard, 1: 100,000: B11G Van Keulenfjorden, Norsk Polarinstitutt, Temakart, 15, 1-58, 1990.
De Souza Sierra, M., Donard, O., Lamotte, M., Belin, C., and Ewald, M.: Fluorescence spectroscopy of coastal and marine waters, Mar. Chem., 47, 127-144, doi:10.1016/03044203(94)90104-X, 1994.

Escher, A. and Watt, W. S.: The geology of Greenland, Geological Survey of Greenland, Copenhagen, 1976.

Fellman, J., D’Amore, D., Hood, E., and Boone, R.: Fluorescence characteristics and biodegradability of dissolved organic matter in forest and wetland soils from coastal temperate watersheds in southeast Alaska, Biogeochem., 88, 169-184, doi:10.1007/s10533-008-9203-x, 2008.

Ferrari, G. M. and Mingazzini, M.: Synchronous FluorescenceSpectra of Dissolved Organic-Matter (Dom) of Algal Origin in Marine Coastal Waters, Mar. Ecol. Prog. Ser., 125, 305-315, 1995.

Foght, J., Aislabie, J., Turner, S., Brown, C. E., Ryburn, J., Saul, D. J., and Lawson, W.: Culturable bacteria in subglacial sediments and ice from two Southern Hemisphere glaciers, Microb. Ecol., 47, 329-340, doi:10.1007/s00248-003-1036-5, 2004.

Grannas, A. M., Hockaday, W. C., Hatcher, P. G., Thompson, L. G., and Mosley-Thompson, E.: New revelations on the nature of organic matter in ice cores, J. Geophys. Res., 111, D04304, doi:10.1029/2005JD006251, 2006.

Hendy, C. H.: Late Quaternary lakes in the McMurdo Sound region of Antarctica, Geografiska Annaler: Series A, Physical Geography, 82, 411-432, doi:10.1111/j.0435-3676.2000.00131.x, 2000.

Hodson, A., Anesio, A. M., Tranter, M., Fountain, A., Osborn, M., Priscu, J., Laybourn-Parry, J., and Sattler, B.: Glacial ecosystems, Ecological Monographs, 78, 41-67, doi:10.1890/070187.1, 2008.

Horwath Burnham, J. and Sletter, R. S.: Spatial distribution of soil organic carbon in northwest Greenland and underestimates of high Arctic carbon stores, Global Biogeochem. Cy., 24, GB3012, doi:10.1029/2009gb003660, 2010.

Hood, E., Fellman, J., Spencer, R., Hernes, P., Edwards, R., D'Amore, D., and Scott, D.: Glaciers as a source of ancient and labile organic matter to the marine environment, Nature, 462, 1044-1047, doi:10.1038/nature08580, 2009.

Hubbard, B. and Sharp, M.: Basal ice formation and deformation: a review, Prog. Phys. Geogr., 13, 529-558, doi:10.1177/030913338901300403, 1989.

Hubbard, B., Cook, S., and Coulson, H.: Basal ice facies: a review and unifying approach, Quaternary Sci. Rev., 28, 1956-1969, doi:10.1016/j.quascirev.2009.03.005, 2009.

Iverson, N. R. and Semmens, D. J.: Intrusion of ice into porous media by regelation: A mechanism of sediment entrainment by glaciers, J. Geophys. Res.-Solid Earth, 100, 10219-10230, doi:10.1029/95JB00043, 1995.

Jansen, K., Stupperich, E., and Fuchs, G.: Carbohydrate synthesis from acetyl CoA in the autotroph Methanobacterium thermoautotrophicum, Archives Microbiol., 132, 355-364, doi:10.1007/BF00413389, 1982.

Jansson, P., Kohler, J., and Pohjola, V. A. Characteristics of basal ice at Engabreen, northern Norway, Ann. Glaciol., 22, 114-120, 1996.

Jensen, M., Holmer, M., and Thamdrup, B. Composition and diagenesis of neutral carbohydrates in sediments of the BalticNorth Sea transition, Geochim. Cosmochim. Acta, 69, 40854099, doi:10.1016/j.gca.2005.01.021, 2005. 
Kastovska, K., Stibal, M., Sabacka, M., Cerna, B., Santruckova, H., and Elster, J.: Microbial community structure and ecology of subglacial sediments in two polythermal Svalbard glaciers characterized by epifluorescence microscopy and PLFA, Polar Biol., 30, 277-287, doi:10.1007/s00300-006-0181-y, 2007.

Kirchman, D. L., Meon, B., Ducklow, H. W., Carlson, C. A., Hansell, D. A., and Steward, G. F.: Glucose fluxes and concentrations of dissolved combined neutral sugars (polysaccharides) in the Ross Sea and Polar Front Zone, Antarctica, Deep Sea Res. Pt. II, 48, 4179-4197, doi:10.1016/S0967-0645(01)00085-6, 2001.

Knight, P.: The basal ice layer of glaciers and ice sheets, Quaternary Sci. Rev., 16, 975-993, doi:10.1016/S0277-3791(97)000334, 1997.

Knight, P., Waller, R., Patterson, C., Jones, A., and Robinson, Z.: Discharge of debris from ice at the margin of the Greenland ice sheet, J. Glaciol., 48, 192-198, 2002.

Larsen, N. K., Kronborg, C., Yde, J. C., and Knudsen, N. T.: Debris entrainment by basal freeze-on and thrusting during the 1995-1998 surge of Kuannersuit Glacier on Disko Island, west Greenland, Earth Surf. Process. Landforms, 35, 561-574, doi:10.1002/esp.1945, 2010.

Lawson, D. E., Strasser, J. C., Evenson, E. B., Alley, R. B., and Larson, G. J., Arcone, S. A.: Glaciohydraulic supercooling: a freezeon mechanism to create stratified, debris-rich basal ice: I. Field evidence, J. Glaciol., 44, 547-567, 1998.

Lawson, E. C., Bhatia, M. P., Wadham, J. L., and Kujawinski, E. B.: Continuous summer export of nitrogen-rich organic matter from the Greenland Ice Sheet inferred by ultrahigh resolution mass spectrometry, Environ. Sci. Technol., 48, 14248-14257, doi:10.1021/es501732h, 2014a.

Lawson, E. C., Wadham, J. L., Tranter, M., Stibal, M., Lis, G. P., Butler, C. E. H., Laybourn-Parry, J., Nienow, P., Chandler, D., and Dewsbury, P.: Greenland Ice Sheet exports labile organic carbon to the Arctic oceans, Biogeosciences, 11, 4015-4028, doi:10.5194/bg-11-4015-2014, 2014b.

Liest $\varnothing 1$, O.: Glacier surges in west Spitsbergen, Can. J. Earth Sci., 6, 895-897, 1999.

Mader, H. M., Pettitt, M. E., Wadham, J. L. E., Wolff, E. W., and Parkes, R. J.: Subsurface ice as a microbial habitat, Geology, 34, 169-172, doi:10.1130/G22096.1, 2006.

Maupetit, F. O. and Delmas, R. J.: Carboxylic acids in highelevation Alpine glacier snow, J. Geophys. Res., 99, 1649116500, doi:10.1029/94JD03315, 1994.

McKnight, D. M., Boyer, E. W., Westerhoff, P. K., Doran, P. T., Kulbe, T., and Andersen, D. T.: Spectrofluorometric characterization of dissolved organic matter for indication of precursor organic material and aromaticity, Limnol. Oceanogr., 46, 38-48, doi:10.4319/lo.2001.46.1.0038, 2001.

Meyers, P. and Ishiwatari, R. Lacustrine organic geochemistryan overview of indicators of organic matter sources and diagenesis in lake sediments, Org. Geochem., 20, 867-900, doi:10.1016/0146-6380(93)90100-P, 1993.

Miano, T. M. and Senesi, N.: Synchronous Excitation Fluorescence Spectroscopy Applied to Soil Humic Substances Chemistry, Sci. Total Environ., 118, 41-51, doi:10.1016/0048-9697(92)90071Y, 1992.

Montross, S. N., Skidmore, M., Tranter, M., Kivimäki, A. L., and Parkes, R. J.: A microbial driver of chemical weathering in glaciated systems, Geology, 41, 215-218, doi:10.1130/G33572.1, 2012.

Paterson, W.: The physics of glaciers, 3rd edition ed, Oxford, 1999.

Pautler, B. G., Simpson, A. J., Simpson, M. J., Tseng, L. H., Spraul, M., Dubnick, A., Sharp, M. J., and Fitzsimons, S. J.: Detection and Structural Identification of Dissolved Organic Matter in Antarctic Glacial Ice at Natural Abundance by SPR-W5WATERGATE 1H NMR Spectroscopy, Environ. Sci. Technol., 45, 4710-4717, doi:10.1021/es200697c, 2011.

Pautler, B. G., Woods, G. C., Dubnick, A., Simpson, A. J., Sharp, M. J., Fitzsimons, S., and Simpson, M. J.: Molecular characterization of dissolved organic matter in glacial ice: Coupling natural abundance 1H NMR and fluorescence spectroscopy, Environ. Sci. Technol., 46, 3753-3761, doi:10.1021/es203942y, 2012.

Péwé, T. L.: Multiple glaciation in the McMurdo Sound region, Antarctica: A progress report, J. Geol., 68, 498-514, 1960.

Porter, K. G. and Feig, Y. S.: The use of DAPI for identifying and counting aquatic microflora, Limnol. Oceanogr., 25, 943-948, doi:10.4319/lo.1980.25.5.0943, 1980.

Pusceddu, A., Dell'Anno, A., Fabiano, M., and Danovaro, R.: Quantity and bioavailability of sediment organic matter as signatures of benthic trophic status, Mar. Ecol. Prog. Ser., 375, 41-52, doi:10.3354/meps07735, 2009.

Rich, J., Gosselin, M., Sherr, E., Sherr, B., and Kirchman, D. L.: High bacterial production, uptake and concentrations of dissolved organic matter in the Central Arctic Ocean, Deep Sea Res. Part II, 44, 1645-1663, doi:10.1016/S0967-0645(97)00058$1,1997$.

Saigne, C., Kirchner, S., and Legrand, M.: Ion-chromatographic measurements of ammonium, fluoride, acetate, formate and methanesulphonate ions at very low levels in antarctic ice, Anal. Chim. Acta, 203, 11-21, doi:10.1016/0003-2670(87)90003-1, 1987.

Schillawski, S. and Petsch, S.: Release of biodegradable dissolved organic matter from ancient sedimentary rocks, Global Biogeochem. Cy., 22, GB3002, doi:10.1029/2007GB002980, 2008.

Sharp, M. J., Jouzel, J., Hubbard, B., and Lawson, W.: The character, structure and origin of the basal ice layer of a surge-type glacier, J. Glaciol., 40, 327-340, 1994.

Sharp, M., Parkes, J., Cragg, B., Fairchild, I. J., Lamb, H., and Tranter, M.: Widespread bacterial populations at glacier beds and their relationship to rock weathering and carbon cycling, Geology, 27, 107-110, doi:10.1130/00917613(1999)027<0107:WBPAGB>2.3.CO;2, 1999.

Simpson, M. J. R., Milne, G. A., Huybrechts, P., and Long, A. J.: Calibrating a glaciological model of the Greenland ice sheet from the Last Glacial Maximum to present-day using field observations of relative sea level and ice extent, Quaternary Sci. Rev., 28, 1631-1657, doi:10.1016/j.quascirev.2009.03.004, 2009.

Singh, B. K.: Biosynthesis of valine, leucine, and isoleucine. Plant amino acids: biochemistry and biotechnology, New York, Marcel Dekker, 227-247, 1999.

Skidmore, M. L., Foght, J. M., and Sharp, M. J.: Microbial life beneath a high Arctic glacier, Appl. Environ. Microbiol., 66, 3214 3220, doi:10.1128/AEM.66.8.3214-3220.2000, 2000.

Skoog, A. and Benner, R. Aldoses in Various Size Fractions of Marine Organic Matter: Implications for Carbon Cycling, Limnol. Oceanogr., 42, 1803-1813, doi:10.4319/lo.1997.42.8.1803, 1997. 
Squyres, S. W., Andersen, D. W., Nedell, S. S., and Wharton Jr., R. A.: Lake Hoare, Antarctica: sedimentation through a thick perennial ice cover, Sedimentology, 38, 363-379, doi:10.1111/j.13653091.1991.tb01265.x, 1991.

Stibal, M., Lawson, E., Lis, G., Mak, K., Wadham, J., and Anesio, A.: Organic matter content and quality in supraglacial debris across the ablation zone of the Greenland ice sheet, Ann. Glaciol., 51, 1-8, doi:10.3189/172756411795931958, 2010.

Stibal, M., Wadham, J. L., Lis, G. P., Telling, J., Pancost, R. D., Dubnick, A., Sharp, M. J., Lawson, E. C., Butler, C. E. H., and Hasan, F.: Methanogenic potential of Arctic and Antarctic subglacial environments with contrasting organic carbon sources, Glob. Change Biol., 18, 3332-3345, doi:10.1111/j.1365-2486.2012.02763.x, 2012.

Stubbins, A., Hood, E., Raymond, P. A., Aiken, G. R., Sleighter, R. L., Hernes, P. J., Butman, D., Hatcher, P. G., Striegl, R. G., and Schuster, P.: Anthropogenic aerosols as a source of ancient dissolved organic matter in glaciers, Nature Geosci., 5, 198-201, doi:10.1038/ngeo1403, 2012.

Stuiver, M., Denton, G. H., Hughes, T. J., and Fastook, J. L.: History of the marine ice sheet in West Antarctica during the last glaciation: a working hypothesis, in: The Last Great Ice Sheets, edited by: Denton, G. H. and Hughes, T. J., 319-436, John Wiley and Sons, New York, 1981.

Sugden, D., Knight, P., Livesey, N., Lorrain, R., Souchez, R., Tison, J.-L., and Jouzel, J.: Evidence for two zones of debris entrainment beneath the Greenland ice sheet, Nature, 328, 238-241, doi:10.1038/328238a0, 1987.

Tison, J. L., Souchez, R., Wolff, E. W., Moore, J. C., Legrand, M. R., and de Angelis, M.: Is a periglacial biota responsible for enhanced dielectric response in basal ice from the Greenland Ice Core Project ice core?, J. Geophys. Res., 103, 18885-18894, doi:10.1029/98JD01107, 1998.
Valle, J., Da Re, S., Schmid, S., Skurnik, D., D’Ari, R., and Ghigo, J. M.: The amino acid valine is secreted in continuous-flow bacterial biofilms, J. Bacteriol., 190, 264-274, doi:10.1128/JB.0140507, 2008.

Wadham, J. L., Bottrell, S., Tranter, M., and Raiswell, R.: Stable isotope evidence for microbial sulphate reduction at the bed of a polythermal high Arctic glacier, Earth Planet. Sci. Lett., 219, 341-355, doi:10.1016/S0012-821X(03)00683-6, 2004.

Wadham, J. L., Cooper, R. J., Tranter, M., and Bottrell, S.: Evidence for widespread anoxia in the proglacial zone of an Arctic glacier, Chem. Geol., 243, 1-15, doi:10.1016/j.chemgeo.2007.04.010, 2007.

Wadham, J. L., Tranter, M., Tulaczyk, S., and Sharp, M.: Subglacial methanogenesis: A potential climatic amplifier?, Global Biogeochem., Cy., 22, GB2021, doi:10.1029/2007GB002951, 2008

Waller, R., Hart, J., and Knight, P.: The influence of tectonic deformation on facies variability in stratified debris-rich basal ice, Quaternary Sci. Rev., 19, 775-786, 2000.

Yamashita, Y. and Tanoue, E.: Chemical characterization of proteinlike fluorophores in DOM in relation to aromatic amino acids, Mar. Chem., 82, 255-271, doi:10.1016/S0304-4203(03)000732, 2003.

Yde, J., Riger-Kusk, M., Christiansen, H., Knudsen, N., and Humlum, O.: Hydrochemical characteristics of bulk meltwater from an entire ablation season, Longyearbreen, Svalbard, J. Glaciol., 54, 259-272, doi:10.3189/002214308784886234, 2008.

Yde, J. C., Finster, K. W., Raiswell, R., Steffensen, J. P., Heinemeier, J., Olsen, J., Gunnlaugsson, H. P., and Nielsen, O. B.: Basal ice microbiology at the margin of the Greenland ice sheet, Ann. Glaciol., 51, 71-79, 2010. 